\title{
ALKITAB DAN HUBUNGAN PERTEMANAN KAJIAN TEOLOGI PENTAKOSTA MEMAKNAI HUBUNGAN PERTEMANAN DALAM ALKITAB
}

\author{
Kosma Manurung \\ STT Intheos Surakarta \\ kosmamanurung@sttintheos.ac.id
}

Diterima tanggal: 26 Juni 2021

Dipublikasikan tanggal: 30 Juni 2021

\begin{abstract}
ABSTRAK
Artikel ini bermaksud memaknai hubungan pertemanan di dalam Alkitab melalui kajian teologi Pentakosta. Metode yang digunakan dalam penelitian artikel ini adalah analisis teks dan kajian literatur. Artikel ini membahas tiga contoh hubungan pertemanan yaitu pertemanan Daud dan Yonatan, Daniel dan ketiga sahabatnya, maupun Paulus dan Silas. Berdasarkan hasil penelitian artikel ini hubungan pertemanan dibangun berdasarkan komitmen, sikap rela berkorban, dan kesetiakawanan. Adapun Maksud Allah merancang hubungan pertemanan adalah sebagai komunitas ilahi yang melaluinya orang percaya mendapatkan kekuatan dan peneguhan sehingga berdampak bagi Kerajaan Allah.
\end{abstract}

Kata Kunci: hubungan pertemanan; prinsip pertemanan; kajian pentakosta; teologi pentakosta

\section{ABSTRACK}

This article intends to interpret the relationship of friendship in the Bible in the study of Pentecostal theology. The method used in this article research is text analysis and literature review. This article discusses three examples of friendship relationships, namely the friendship of David and Jonathan, Daniel and his three friends, and Paul and Silas. Based on the results of this article's research, friendship is built on commitment, self-sacrifice, and flock loyalty. The purpose of God designing friendship relationships is as a divine community through which believers get strength and confirmation so that they have an impact on the Kingdom of God.

Keywords: friendship relationship; the principle of friendship; pentecostal studies; pentecostal theology 


\section{PENDAHULUAN}

Manusia adalah mahluk sosial yang tidak akan pernah bisa hidup hanya sendirian saja tanpa ada manusia lainnya (Simbolon, 2018, p. 40-52). Alkitab juga memberikan gambaran yang sama tentang manusia sebagai mahluk sosial dalam menjalani hidupnya, mendapatkan kebermaknaan, dan menghidupi tujuan yang Allah inginkan (Kej. 1:26). Hal ini berarti bahwa kebutuhan akan adanya teman adalah sebuah kebutuhan yang mutlak ada dan tidak bisa dihindari dari konsekuensi manusia sebagai mahluk sosial (Xiao, 2018, p. 94-99). Tanda yang paling nyata dan mudah terbaca dari hakikat manusia sebagai mahluk sosial ini adalah adanya tuntutan dari dalam diri manusia itu sendiri untuk selalu berkomunikasi dan berelasi dengan manusia lainnya (Najla, 2018, p. 100-108).

Tuntutan untuk berhubungan secara sosial ini dapat berdampak buruk apabila tidak dibarengi dengan pemahaman yang benar. Hal ini dikarenakan terdapat nilai-nilai yang bisa jadi bertentangan antara satu orang dengan orang yang lainnya (Diananda, 2019, p. 116-133). Misalnya persahabatan antara Amnon dan Yonadab yang akhirnya menjerumuskan Amnon pada tindakan amoral ( 2 Sam. 13:1-22). Kondisi seperti ini biasanya paling rentan terjadi pada anak-anak usia remaja, tetapi tidak menutup kemungkinan juga dapat terjadi pada orang dewasa. Di sinilah terlihat bahwa pengaruh teman berkontribusi besar dalam perilaku seseorang (Dwi Fitria, Muswardi, and Mayasari, 2017, p. 53-67). Terkait dengan pertemanan ini, Alkitab memberikan peringatan kepada orang percaya untuk berhati-hati dalam memilih teman karena pergaulan yang buruk pastilah merusak kebiasaan yang baik (1 Kor. 15:33).

Allah menuntut perilaku yang berbeda dari orang percaya ketika membangun komunikasi dan berelasi dengan sesama, sebab terdapat mandat surgawi yang menuntut orang percaya untuk selalu menjadi garam dan terang dalam kehidupannya (Dwiraharjo, 2018, p. 1-24). Yesus adalah teladan utama sekaligus juga contoh sempurna bagaimana seharusnya orang percaya berperilaku, ini berarti setiap tindakan dan perilaku orang percaya harus disesuaikan dengan apa yang sudah Tuhan Yesus lakukan. Misalnya bagaimana Dia berkomunikasi dan membangun relasi pertemanan dengan para muridNya (Ibrahim Boiliu et al., 2020, p. 61-72). Bagi kaum Pentakosta hubungan pertemanan adalah hal yang penting bagi manusia. Itulah mengapa tidak heran jika suasana kekeluargaan dan saling sapa terlihat sangat kental dalam perayaan ibadahnya. 
Bahkan dalam banyak hal suasana tersebut berkembang menjadi hubungan pertemanan di antara jemaat yang ada (Supatra 2019, p. 11-24), yang pada gilirannya hubungan pertemanan ini membentuk kepercayaan dan kerjasama di kalangan sesama komunitas lokal atau saudara seiman (Nel, 2018, p. 8). Selanjutnya dalam artikel ini peneliti ingin mengkaji pandangan teologi Pentakosta dalam memaknai hubungan pertemanan yang ada di Alkitab.

\section{METODE}

Dalam artikel ini peneliti menggunakan metode kualitatif dengan pendekatan analisis teks dan kajian literatur. Tujuan dari penelitian ini adalah ingin mencari makna dan memahami permasalahan yang sedang dibahas (S. E. Zaluchu, 2020, p. 28). Analisis teks sendiri bisa dipahami sebagai sebuah usaha untuk menganalisis teks Alkitab dengan mendalami konteks penulisannya (Soesilo, 2018, p. 136-151). Pada artikel ini peneliti menggunakan analisis teks ketika menjelaskan lebih jauh tentang ketiga contoh hubungan pertemanan yaitu Daud dan Yonatan, Daniel dan ketiga sahabatnya, maupun hubungan pertemanan Paulus dan Silas. Ketiga contoh yang diangkat kemudian dikaji dengan menekankan pada sudut pandang kaum Pentakosta. Artinya analisis teks ketiga bagian ini dinarasikan dalam bingkai teologi Pentakosta. Kajian literatur sendiri bisa dimaknai sebagai proses kajian yang penekanannya pada sumber tertulis (Subekt et al., 2017, p. 81-90). Kajian literatur peneliti gunakan untuk memperkuat dan memperjelas pemahaman dari contoh-contoh yang peneliti analisis. Adapun kajian literatur yang digunakan dalam artikel ini adalah dari buku dan jurnal ilmiah yang terkait dengan topik pembahasan maupun yang memiliki irisan dengan topik yang sedang peneliti bahas.

\section{HASIL DAN PEMBAHASAN}

\section{Contoh-Contoh Alkitab}

\section{Daud dan Yonathan}

Di dalam 1 Samuel 18 dikisahkan tentang peristiwa setelah Daud mengalahkan Goliat. Kala itu Saul memanggilnya untuk berbicara. Ketika Daud selesai berbicara dengan Saul, Alkitab mengambarkan berpadulah jiwa Daud dan jiwa Yonatan, dan Alkitab melanjutkan Yonatan mengikat perjanjian dengan Daud karenaYonatan 
mengasihi Daud seperti dirinya sendiri. Kata berpadu ( 1 Samuel 18:1) di sini berasal dari kata (qashar) dalam bahasa aslinya, yang bisa dimaknai dengan jiwa dari akal sehat yang terikat karena sependapat sehingga melahirkan kekompakan. Kata mengasihi אהב (ahab) yang bisa juga dipahami sebagai rasa sayang seseorang terhadap dirinya sendiri. Perlu peneliti tekankan di sini mengacu pada bahasa aslinya, ungkapan Alkitab tentang Yonatan mengasihi Daud, tidak ada hubungannya dengan gairah seksual. Karena banyaknya pandangan yang menyalahartikan rasa sayang Yonatan kepada Daud sebagai rasa sayang yang mengarah pada gairah seksual atau naluri seksual. Hal ini tentu sangat tidak berdasar, dan Taurat sendiri yaitu firman Allah dan hukum yang dipakai di zaman raja Daud, sangatlah menentang hal itu (Sitopu, 2020, p. 33-44). Kitab Imamat menulis bahwa di dalam bangsa Israel tidak boleh ada persetubuhan sesama jenis di Israel; kalau itu terjadi hukumannya mati (Im. 20:13). Alkitab lebih lanjut menceritakan semenjak peristiwa itu dan seterusnya baik Yonatan maupun Daud tetap dalam hubungan pertemanan yang telah mereka ikat bersama.

Jika mengalihkan sudut pandang terkait dengan kelanjutan pertemanan ini dari sisi Yonatan tentu hal ini bukan perkara mudah bagi Yonatan untuk terus berteman dengan Daud, selain faktor raja Saul; ayah Yonatan sangat membenci Daud. Yonatan sendiri juga putra mahkota yang seharusnya mewarisi tahta. Artinya kalau Daud tetap hidup maka ada ancaman paling berbahaya yang akan menghalangi suksesi Yonatan untuk menjadi raja. Disinilah terlihat bagaimana kasih yang rela berkorban itu bukan sekedar diucapkan oleh Yonatan melainkan juga ditunjukannya. Alkitab menggambarkan bahwa kedudukan raja Israel bukan sekedar posisi yang mengandung banyak hak dan kenikmatan yang menanti dengan begitu banyak harta kekayaan namun ada tanggung jawab besar yang Allah berikan kepada seorang raja (Takaendengan, 2018, p. 45-57). Yonatan memahami benar akan hal ini dan memberikan dukungannya untuk Daud menjadi raja Israel selanjutnya (1 Sam. 23:17).

Kaum Pentakosta memaknai persahatan Daud dan Yonantan ini sebagai karunia dan karya Allah dalam kehidupan orang percaya yang dengan cara-Nya Allah menempatkan orang-orang yang hatinya digerakan oleh Roh untuk menopang orangorang pilihan guna menggenapi tujuan Allah dalam hidup mereka (Stansell, 2011, p. 
115). Dari kehidupan raja Daud yang penuh perjuangan dan bagaimana Daud bereaksi terhadap keadaan-keadaan sulit dalam hidupnya serta bagaimana Daud selalu berusaha mengarahkan dirinya untuk selalu berharap dan mendahulukan kehendak Allah adalah kualitas hidup yang bisa diteladani dari seorang Daud (Tua, 2017, p. 75). Hal yang paling penting untuk diingat dari kisah ini adalah apapun yang telah Daud kerjakan dan pencapaiannya itu bukanlah prestasi Daud sendiri melainkan Allah adalah sumber dari semua termasuk sumber dalam hubungan persahabatan Daud dan Yonatan, juga tentunya Allah adalah sumber segala keberhasilan Daud (LASOR, HUBBARD, and BUSH, 2015, p. 341).

\section{Daniel dan Ketiga Temannya}

Kisah persahabatan Daniel, Hananya, Misael, dan Azarya adalah sebuah kisah pertemanan lainnya yang dibahas dalam artikel ini. Keempat teman ini adalah para tawanan perang yang berasal dari wilayah yang sama yaitu dari Kerajaan Yehuda yang ditaklukan oleh Babel. Sebagai tawanan perang pada umumnya tentu ada banyak kesulitan, disepelekan, direndahkan, tidak dihargai, diperlakukan tidak adil dan banyak penderitaan lainnya yang barangkali dialami oleh Daniel dan ketiga temannya. Selain itu biasanya ada semacam mental jajahan dengan gejala perasaan rendah diri sebagai bangsa tawanan yang harus keempat orang ini kalahkan didalam diri mereka. Dengan penentuan Allah, Daniel dan teman-temannya bisa memiliki kesempatan untuk bekerja di dalam istana raja Babel. Yang tentunya memberikan mereka cukup banyak kesempatan untuk saling berinteraksi dan saling menguatkan hal ini terbukti dengan kekompakan mereka ketika dalam ujian iman ( Dan. 3:1-30). Allah memilih Daniel dan teman-temannya untuk keberlangsungan rencana-Nya bagi umat pilihan waktu itu (Manurung, 2020a, p. 129-140).

Kitab Daniel menulis bahwa karena campur tangan Tuhan melalui hikmat yang Tuhan berikan kepada Daniel dan ketiga temannya itu membawa mereka duduk diposisi yang tinggi di pemerintahan Babel waktu itu, hal ini juga mendatangkan kecemburuan dan rasa iri dari orang-orang yang bekerja di istana bahkan dari pejabat-pejabat pemerintahan Babel. Segala upaya diusahakan untuk menjatuhkan Daniel dan ketiga 
temannya, namun tidak ada yang berhasil karena memang integritas dan etos kerja mereka diatas rata-rata. Satu-satunya cara yang bisa dipikirkan oleh para pejabat yang iri adalah menjebak dan memfitnah Daniel juga teman-temannya terkait dengan kepada siapa mereka berdoa dan menyembah. Akibat cara licik yang lahir dari perasaan iri dan dengki yang digunakan para pejabat Babel waktu itu Sadrak (Hananya), Mesakh (Misael), dan Abednego (Azarya) harus mengalami dilempar di perapian yang menyalanyala yang dipanaskan tujuh kali atas perintah Nebukadnezar. Tidak ada satupun dari ketika sahabat ini yang saling menghianati, mengambil jalan pintas dengan menjerumuskan teman sendiri, ataupun mencari kambing hitam. Mereka bertiga tidak saling menyalahkan, melainkan dengan sepakat mengaku kekuasaan Tuhan walaupun "ajal sudah di depan mata".

Begitu juga dengan Daniel, karena kedengkian pejabat lain di istana waktu itu akan posisinya, dengan cara licik mereka akhirnya bisa "menyingkirkan" Daniel dari istana dan mengungsikan Daniel untuk bermalam di gua singa tidur ditemani singasinga yang kelaparan ( Dan. 6:1-29). Namun singa yang kelaparan itu tidak menyentuh Daniel dan lewat peristiwa lolosnya Daniel dari singa yang kelaparan ini nama Tuhan justru dimuliakan dan ada perintah dari raja Darius ke seluruh wilayah kekuasaannya bahwa orang harus takut dan gentar terhadap Allahnya Daniel. Bagi kaum Pentakosta ketika membaca cerita Daniel dan teman-temannya, ada pesan teologis yang kuat, menginspirasi, dan membangkitkan iman dalam kisah ini ((Pranoto, 2017, p. 81). Nilai rohani yang dilihat oleh kaum Pentakosta dari cerita ini adalah ketika iman pengharapan Daniel dan ketiga sahabatnya mengalami tantangan yang sangat berat dan tidak ada harapan lagi dari pertolongan manapun kecuali Allah Israel yang mereka sembah maka Allah dengan kuasa-Nya membela Daniel dan teman-temannya (Benyamin, 2019, p. 4859). Kisah Daniel dan ketiga temannya memperlihatkan dengan jelas pesan yang ingin Allah sampaikan bahwa Ia berdaulat mutlak atas semua urusan manusia (Nainggolan, 2019, p. 11-21).

\section{Paulus dan Silas}

Rasul Paulus adalah rasul terbesar di Perjanjian Baru yang sumbangan tulisantulisannya sarat makna dengan kedalaman dan kekayaan teologis (Setiawan and Yulianingsih, 2019, p. 227-246). Dalam hidupnya rasul Paulus memiliki beberapa 
teman semisal Lukas, Barnabas, pasangan Akwila dan Priskila, dan teman-teman lainnya. Pada bagian artikel ini peneliti akan membahas pertemanan Paulus dan Silas. Jika mengkaji Kisah Para Rasul 15, terdapat sedikit keunikan dari latar belakang hubungan pertemanan Paulus dan Silas. Di situ terdapat cerita tentang konflik perpisahan Paulus dan Barnabas yang berujung pada perpisahan keduanya. Paulus membawa Silas menjadi teman pelayanannya dan Barnabas membawa Yohanes Markus. Sayangnya cerita konflik Paulus dan Barnabas ini dimaknai berbeda oleh beberapa gereja sebagai alasan untuk memisahkan diri dengan tidak adanya rekonsiliasi dikemudian hari dari perpisahan tersebut (S. E. Zaluchu, 2018, p. 107-117). Padahal dikemudian hari selain pelayanan Paulus dan Barnabas masing-masing melebarkan sayap Kerajaan Allah, ada rekonsiliasi juga diantara mereka yang memuliakan Allah (Setyowati, 2019, p. 33).

Paulus dan Silas yang pada hakekatnya memiliki gairah yang sama sehingga menjadikan hubungan pertemanan mereka akrab (Silalahi, 2019, p. 1-18). Sudah menjadi rahasia umum juga di zaman modern ini bahwa kesamaan selera, gairah, atau hobi akan menjadi jembatan untuk menyatukan banyak orang dari berbagai kalangan. Semisal menyukai grup band yang sama, menyukai grup sepak bola yang sama, ataupun dalam hal yang berbau rohani menyukai gereja atau pengkhotbah yang sama akan menjadi jembatan yang membuka jalan untuk terciptanya pertemanan. Namun jika mengkaji lebih jauh tentang hubungan pertemanan Paulus dan Silas ini, bisa dimaknai bahwa pertemanan keduanya bukan karena inisiatif pribadi mereka melainkan ada campur tangan Tuhan yang tidak terlihat yang menuntun mereka masuk dalam hubungan pertemanan tersebut (S. E. Zaluchu, 2018, p. 107-117).

French L. Arrington dalam bukunya Doktrin Kristen Perspektif Pentakosta menyatakan bahwa Alkitab memberikan gambaran waktu manusia diciptakan, Allah menciptakan manusia segambar dan serupa dengan Allah untuk merefleksikan dan mewakili Allah (Arrington, 2020, p. 241). Sayangnya dunia yang orang percaya hidupi hari ini adalah dunia yang sudah terkotori oleh dosa, ketika uang menjadi alat ukur hampir di semua lini kehidupan, tak terkecuali dalam hubungan pertemanan. Terkait hal ini, peneliti menanggapi bahwa hubungan pertemanan Paulus dan Silas, sangat merefleksikan serta mewakili Allah (J. Zaluchu, 2019, p. 10-22). Nilai moral dan nilai 
teologis untuk merefleksikan dan mewakili Allah dalam hubungan pertemanan inilah yang seharusnya menjadi dasar sekaligus juga motor penggerak bagi orang percaya untuk membangun hubungan pertemanan.

\section{Prinsip-Prinsip Tentang Pertemanan}

\section{Komitmen}

Komitmen dibutuhkan sebagai fondasi dari setiap hubungan tak terkecuali hubungan pertemanan (Novita, Sunuharjo, and Ruhana, 2016, p. 38-46). Tak bisa dipungkiri bahwa komitmen berpengaruh langsung pada tindakan seseorang, misalnya saja ketika seseorang masuk dalam sebuah komitmen perjanjian kerja dari pencari kerja ke karyawan kontrak kemudian menjadi karyawan tetap akan terlihat jelas pengaruh langsung yang diperlihatkan karyawan tersebut, tentunya komitmen kerjanya akan semakin meningkat (Hendrajana, Sintaasih, and Saroyeni P, 2016, p. 33-44). Alkitab memberikan gambaran bahwa Allah adalah Allah yang berkomitmen pada setiap perkataan-Nya, hal ini berarti untuk setiap ucapan yang keluar dari mulut-Nya Allah akan berusaha dengan sekuat tenanga untuk menggenapi (Manurung, 2020a, p. 129140). Bagi kaum Pentakosta komitmen Allah yang memegang janji-Nya ini menjadi semacam motivasi tersendiri untuk berharap dan percaya terus dengan Allah (Sutoyo, 2018, p. 167).

Komitmen dibutuhkan bukan sekedar untuk memulai hubungan pertemanan tetapi komitmen lebih dibutuhkan ketika seiring berjalannya waktu hubunggan pertemanan itu diterpa ujian-ujian yang mendesak dan coba menjerumuskannya ke titik perpecahan (S. E. Zaluchu, 2019, p. 75-88). Komitmen begitu kuat mengikat persahabatan Daud dan Yonatan. Komitmen mereka menjadi lebih kuat karena mereka melibatkan Allah dalam untuk menjadi saksi dari hubungan pertemanan ini (1 Sam. 20:16-17). Alkitab menjelaskan lebih lanjut bagaimana Daud memegang komitmen hubungan pertemanan yang dia buat dengan Yonatan dihadapan Allah ini. Hal ini dibuktikan ketika Yonatan meninggal karena peperangan dengan orang Filistin dan ketika Daud telah menjadi raja seluruh Israel, Daud tidak melupakan janji pertemanan yang dia buat dengan Yonatan, Daud mencari keturunan Yonatan untuk menunjukan kebaikannya demi persahabatannya dengan Yonatan. Penulis kitab Samuel begitu piawai mengambarkan bagaimana Daud mencurahkan kebaikannya pada Mefiboset 
anak Yonatan yang adalah sahabatnya dan memperlakukan Mefiboset seperti salah satu putranya (2 Sam. 9).

\section{Rela Berkorban}

Prinsip selanjutnya yang harus ada dalam membangun hubungan pertemanan adalah sikap rela berkorban yang seharusnya juga menjadi gaya hidup dari orang percaya (Kartika, 2018, p. 135-147). Sikap rela berkorban ini tidak mungkin dimiliki oleh seseorang jika orang tersebut tidak berani menyangkali dirinya. Menyangkal dalam artian disini yaitu mengikis egoisme serta kemauan untuk menanggung beban dari rasa kehilangan sesuatu bahkan mungkin sesuatu yang sangat berharga, karena tak bisa dipungkiri berkorban artinya kita kehilangan sesuatu yang barangkali paling kita ingini (Yonathan, 2019, p. 121-137). Apa yang Yonatan lakukan untuk hubungan pertemanannya dengan Daud adalah contoh yang sangat jelas dari prinsip rela berkorban ini, bagaimana Yonatan melakukan pengorbanan karena hubungan pertemanannya dengan Daud harus rela dibenci oleh ayahnya, raja Saul bahkan pada suatu titik dilempar dengan tombak oleh Ayahnya. Tidak cukup sampai disitu bahkan pengorbanan Yonatan juga dalam hal memberikan dukungan politik kepada Daud untuk menjadi raja selanjutnya padahal Yonatan sendiri adalah putra mahkota yang menurut kebiasaan jaman itu seharusnya menjadi raja.

Alkitab juga secara khusus memberikan tempat arti penting pengorbanan bagi kemanusiaan (Alakaman, 2018, p. 15-34). Perjanjian Baru berkali-kali mengambarkan bagaimana dalam hidup dan pelayanan-Nya dalam rupa manusia di muka bumi Tuhan Yesus melakukan tindakan-tindakan yang bisa dimaknai sebagai sikap yang rela berkorban, yang puncaknya terlihat pada apa yang Tuhan Yesus lakukan melalui karya salib-Nya memberikan contoh yang sempurna apa itu sikap rela berkorban (Berutu, 2020, p. 76-83). Melalui karya salib-Nya Tuhan menunjukan dengan perbuatan arti pengorbandan diri dan sekaligus juga memberikan teladan bagi setiap orang percaya. Sikap rela berkorban yang Tuhan tunjukan ini dimaknai oleh kaum Pentakosta sebagai karakteristik ilahi dari prinsip hubungan pertemanan (Siahaan, 2017, p. 12).

\section{Kesetiakawanan}


Perkembangan peradaban manusia modern seabad kebelakang tidak bisa terlepas dari pengaruh Pentakosta didalamnya karena bagaimanapun juga sedikit banyak ada sentuhan pengaruh Pentakosta (Soesilo, 2018, p. 136-151). Misalnya saja sudut pandang rohani yang menurut Jan S. Aritonang sebagai salah satu aliran gereja yang spektakuler dalam perkembangannya, selain itu pengaruh Pentakosta juga menyentuh modernitas dan kaum urban di Indonesia (Tambunan 2019, p. 99-129). Kaum Pentakosta meyakini benar bahwa Alkitab aturan tertulis tertinggi sebagai standar hidup orang percaya saat ini menyatakan bahwa Allah adalah Allah yang setia (Manurung, 2019, p. 37-54). Kesetiaan Allah pada perkataannya ini kemudian menginspirasi kaum Pentakosta untuk bertindak setia, teristimewa setia dalam hubungan pertemanan (Siahaan, 2017, p. 12).

Zaluchu mewakili kalangan Pentakosta ketika merumuskan ciri kehidupan rohani jemaat mula-mula menyatakan bahwa jemaat mula-mula memiliki gaya hidup yang peduli terhadap sesama (Zaluchu, 2019, p. 72). Dari pernyataan ini dapat dibangun sebuah pemahaman kalau terhadap sesama saja sangat peduli maka pada teman dekat pastinya lebih peduli lagi. Kepedulian pada teman kemudian melahirkan kesetiakawanan. Sikap setia kawan akan menampakan dirinya dengan jelas ketika teman bermasalah atau barang kali menjadi sasaran masalah, maka kita akan memberikan diri untuk menjadi orang terdepan (S. Zaluchu, 2017, p. 61). Inilah contoh yang dilakukan oleh Yonatan bagaimana dengan segenap kemampuannya Yonatan berusaha melindungi Daud bahkan dari ancaman pembunuhan oleh ayahnya sendiri yang coba membunuh Yonatan karena hal itu (1 Sam. 20:33). Biarlah sifat kesetiakawanan Yonatan dan Daud, juga kesetiakawanan yang Daniel dan temantemannya tunjukan, beserta sifat kesetiakawanan yang Paulus dan Silas tunjukkan menjadi penanda dalam memori segenap orang percaya untuk bertindak dalam hubungan pertemanan sehingga nama Tuhan dimuliakan (Susanta, 2018, p. 103).

\section{Arti Penting Pertemanan}

\section{Komunitas Ilahi Yang Allah Rancang.}

Pemberontakan manusia menyebabkan manusia di usir Tuhan keluar dari taman Eden, taman yang selama ini bukan sekedar tempat tinggal bagi manusia melainkan juga sebuah komunitas ilahi saat manusia bisa bersekutu secara bebas dengan Allah (Manurung, 2020b, p. 94-109). Alkitab menceritakan ada begitu banyak dampak buruk 
yang terjadi dalam kehidupan umat manusia setelah peristiwa keluarnya Adam dan Hawa dari komunitas ilahi di taman Eden ini. Tak bisa dipungkiri pengaruh paling kuat yang mengisi kehidupan anak-anak adalah kedua orang tua mereka, hal ini tentunya senada dengan apa yang Alkitab nyatakan bahwa Allah meletakan tanggung jawab untuk mendidik dan mengarahkan anak ada pada kedua orang tuanya (J. Purba, 2018, p. 35-48). Namun sayangnya dalam banyak kesempatan ketidak harmonisan orang tua di rumah menyebabkan anak-anak mencari keharmonisan diluar rumah dan mereka akhirnya menemukan komunitas yang membuat mereka diterima dan nyaman.

Peneliti menemukan bahwa seperti halnya keluarga dan gereja yang Allah rancang sebagai komunitas ilahi, hubungan pertemanan pun sebetulnya dirancang oleh Allah dengan maksud tercipta relasi dan komunitas ilahi yang Allah harapkan melaluinya pesan-pesan maupun tujuan Allah tersampaikan (Remikatu, 2020, p. 65-85). Untuk menjadikan hubungan pertemanan sebagai pintu masuk dalam komunitas ilahi ini, maka orang percaya harus mengalahkan musuh terbesar dalam hidupnya yaitu keakuan atau keegoisannya (Harti, 2019, p. 93-99). Selain menyingkirkan sejauh mungkin ego, komunitas yang lahir dari hubungan pertemanan ini tidak bisa tidak, haruslah juga mencirikan kasih, kerendahan hati, dan kelemah lembutan sebagai karakteristik dari komunitas (Condro, 2020, p. 65-94).

\section{Menguatkan Dan Meneguhkan.}

Hubungan pertemanan Daud dan Yonatan memperlihatkan bagaimana kedua orang teman ini saling menguatkan dan meneguhkan. Ketika Daud lemah, Yonatan akan datang dan meneguhkan Daud untuk mempercayai janji Allah dalam hidupnya (1 Sam. 23:16). Begitu pula sebaliknya, ketika Daud sudah menjadi raja, Dia ingat akan hubungan persahabatan yang sudah Daud buat dengan Yonatan dan memperlakukan (menguatkan) Mefiboset putra Yonatan sebagai putranya dan membawa Mefiboset ke istana raja. Begitu pula cerita Sadrakh, Mesakh, dan Abenego ketiga sahabat Daniel ini ketika menghadapi hukuman dapur api, Alkitab menjelaskan bagaimana ketika sahabat ini saling menguatkan iman dan pengharapan mereka hanya kepada Allah Israel. Alkitab juga menulis sebuah cerita terkait hubungan pertemanan Paulus dan Silas yang saling menguatkan, pada saat pelayanan di Filipi Paulus dan Silas dituduh pengacau dan 
akhirnya dijebloskan ke dalam Penjara. Di dalam perjara inilah kedua sahabat itu saling menguatkan dan meneguhkan, mereka berdoa dan menyanyikan puji-pujian kepada Allah (Kis. 16:25).

Kaum Pentakosta meyakini benar bahwa tidak ada yang kebetulan dalam kehidupan orang percaya, semuanya sudah diatur oleh Tuhan termasuk juga dalam kaitan dengan hubungan pertemanan pastilah semuanya sudah seijin Tuhan dengan maksud untuk memberikan kekuatan dan peneguhan agar orang percaya dapat maksimal mengenapi tujuan Tuhan dalam hidup mereka (Mawikere, 2018, p. 50-67). Ketiga contoh hubungan pertemanan dalam artikel ini memperlihatkan bahwa hubungan pertemanan Tuhan rancang untuk menguatkan dan meneguhkan orang percaya. Setiap hubungan pertemanan ini dilandasi dengan kejujuran dan integritas yang datangnya dari takut akan Allah (Sunariyanti, 2020, p. 107-120).

\section{Berdampak Bagi Kerajaan Allah.}

Allah merancang hubungan pertemanan memiliki dampak bagi Kerajaan Allah (Condro, 2020, p. 65-94). Cerita kehidupan iman Daniel dan ketiga temannya memperlihatkan bagaimana oleh tindakan mereka yang tidak mau berkompromi nilai iman mereka akhirnya mendatangkan pembelaan Allah dan tak cukup hanya itu malah raja bahkan memerintahkan untuk semua orang yang berada di wilayah kerajaannya untuk takut dan hormat pada Allah Israel (Dan. 3:28-29; 6:27-28). Pembahasan artikel ini juga memperlihatkan bahwa pertemanan Paulus dan Silas merupakan contoh bagaimana melalui pertemanan mereka berita Injil semakin berkembang.

Alkitab menggambarkan bahwa menyelamatkan yang terhilang adalah inisiatif Allah sendiri (Yoh. 3:16). Allah langsung turun tangan sendiri melalui wujud kemanusiaan Kristus yang mati di kayu salib, yang oleh orang percaya dimaknai sebagai karya penebusan Allah bagi manusia untuk mengembalikan orang terhilang sehingga memiliki hak kembali untuk bersekutu dalam hubungan ilahi dengan Allah (W. Purba, 2019, p. 22-26). Melalui peristiwa kenaikan-Nya ke surga, Tuhan Yesus memberikan mandat kepada orang percaya untuk juga terlibat dalam Amanat Agung ini (Dwiraharjo, 2019, p. 56-73). Kaum Pentakosta meyakini bahwa setiap orang percaya wajib terlibat dalam mandat ilahi ini dan hubungan pertemanan yang orang percaya bangun seharusnya juga berdampak bagi kerajaan Allah (Soesilo, 2018, p. 136-151). 


\section{SIMPULAN}

Berdasarkan dari hasil penelitian artikel ini dapatlah disimpulkan bahwa Allah merancang hubungan pertemanan sebagai komunitas ilahi yang melaluinya orang percaya mendapatkan kekuatan dan peneguhan sehingga hidupnya berdampak bagi Kerajaan Allah. Alkitab memberikan gambaran bahwa hubungan pertemanan membutuhkan komitmen dari para pihak. Selain itu, siapa saja yang ingin masuk dalam hubungan pertemanan haruslah rela berkorban. Hubungan pertemanan juga menuntut kesetiakawanan. Pertemanan Daud dan Yonatan, Daniel dan ketiga sahabatnya, maupun Paulus dan Silas memperjelas prinsip bahwa baik komitmen, rela berkorban, dan kesetiakawanan adalah hal yang sangat penting dalam sebuah hubungan pertemanan.

\section{DAFTAR PUSTAKA}

Alakaman, Marlen Tineke. 2018. "Yesus Sebagai Hamba, Kajian Kristologi Dan Relevansinya Pada Pelayan Gereja Di Jemaat Gpm Nehemia Sektor Petra.” Kenosis: Jurnal Kajian Teologi 4(1): 15-34. Http://E-

Journal.Iaknambon.Ac.Id/Index.Php/Kns/Article/View/20 (November 26, 2020). Arrington, French L. 2020. Doktrin Kristen Perspektif Pentakosta. Yogyakarta: Andi Offset.

Benyamin, Nefry Christoffel. 2019. "Doa Dan Harapan Akan Allah Yang Membebaskan Sebuah Tafsiran Post-Kolonial Daniel 9:1-27.” Jurnal Abdiel:

Khazanah Pemikiran Teologi, Pendidikan Agama Kristen, Dan Musik Gereja 3(1): $48-59$.

Berutu, Meldayanti. 2020. "Makna Penderitaan Yesus Di Kayu Salib (Eksegetis Lukas 23:33-43) Dan Refleksinya Bagi Umat Kristen Masa Kini.” Areopagus Jurnal Pendidikan Dan Tologi Kristen 18(2): 76-83. Http://EJournal.Iakntarutung.Ac.Id/Index.Php/Areopagus/Article/View/332. Condro, Kuncoro. 2020. "Kepemimpinan Kerajaan Allah Berdasarkan Ucapan Bahagia Ajaran Yesus Kristus Matius 5:3-12.” Sanctum Domine: Jurnal Teologi 8(2): 6594. Https://Journal.Sttni.Ac.Id/Index.Php/Sdjt/Article/View/51 (November 25, 2020). 
Diananda, Amita. 2019. "Psikologi Remaja Dan Permasalahannya." Journal Istighna

1(1): 116-33. Www.Depkes.Go.Id (November 23, 2020).

Dwi Fitria, Restu, Muswardi Muswardi, And Shinta Mayasari. 2017. "Pengaruh

Pergaulan Teman Sebaya Terhadap Motivasi Belajar Siswa.” Alibkin (Jurnal

Bimbingan Konseling) 5(4): 53-67.

Http://Jurnal.Fkip.Unila.Ac.Id/Index.Php/Alib/Article/View/13972.

Dwiraharjo, Susanto. 2018. "Persembahan Yang Hidup Sebagai Buah Dari Pembenaran

Oleh Iman Menurut Roma 12:1-2.” Prudentia: Jurnal Teologi Dan Pendidikan

Kristiani 1(1): 1-24. Http://Www.Sttbaptisjkt.Ac.Id/E-

Journal/Index.Php/Prudentia/Article/View/1.

—. 2019. "Kajian Eksegetikal Amanat Agung Menurut Matius 28:18-20.” Jurnal

Teologi Garcia Deo 1(2): 56-73. Http://Www.Sttbaptisjkt.Ac.Id/E-

Journal/Index.Php/Graciadeo/Article/View/8.

Harti, Sri Dwi. 2019. "Musuh Dalam Diriku.” Jurnal Luxnos 5(2): 93-99.

Http://Luxnos.Sttpd.Ac.Id/Index.Php/20_Luxnos_20/Article/View/18 (November $25,2020)$.

Hendrajana, I G. M. Riko, Desak Ketut Sintaasih, And Putu Saroyeni P. 2016. "Analisis

Hubungan Status Kepegawaian, Komitmen Organisasional Dan Kinerja

Karyawan.” Jurnal Ilmiah Hospitality Management 7(1): 33-44.

Https://Jihm.Stpbipress.Id/Index.Php/Jihm/Article/View/33.

Ibrahim Boiliu, Noh, Aeron Frior Sihombing, Christina M. Samosir, And Fredy

Simanjuntak. 2020. "Mengajarkan Pendidikan Karakter Melalui Matius 5:6-12.”

Kurios (Jurnal Teologi Dan Pendidikan Agama Kristen) 6(1): 61-72.

Https://Www.Sttpb.Ac.Id/E-Journal/Index.Php/Kurios/Article/View/128.

Kalampung, Yan Okhtavianus. 2019. '“Ketika Memori Penderitaan Diperjumpakan '

Sebuah Kajian Dialogis Kitab Daniel Dan Sejarah Penjajahan Jepang Di Indonesia

Dalam Perspektif Poskolonial.” Kenosis: Jurnal Kajian Teologi 4(2): 170-85.

Http://E-Journal.Iaknambon.Ac.Id/Index.Php/Kns/Article/View/66 (November 24, 2020).

Kartika, Rika. 2018. "Menerapkan Kehidupan Sebagai Umat Allah Menurut 1 Petrus

2:11-17." Prudentia: Jurnal Teologi Dan Pendidikan Kristiani 1(2): 135-47. 
Http://Www.Sttbaptisjkt.Ac.Id/E-Journal/Index.Php/Prudentia/Article/View/14. Lasor, W.S., D.A. Hubbard, And F.W. Bush. 2015. Pengantar Perjanjian Lama 1. Jakarta: Bpk Gunung Mulia.

Manurung, Kosma. 2019. "Studi Analisis Kontekstual Ajaran Karunia Nubuat Rasul Paulus Sebagai Dasar Evaluasi Kritis Terhadap Fenomena Bernubuat Di Gereja Beraliran Karismatik.” Dunamis: Jurnal Teologi Dan Pendidikan Kristiani 4(1): 37-54. Https://Sttintheos.Ac.Id/E-Journal/Index.Php/Dunamis/Article/View/189 (November 23, 2019).

—. 2020a. "Ketubim Dan Nubuat." Pengarah: Jurnal Teologi Kristen 2(2): 129

40. Https://10.0.141.174/Pengarah.V2i2.24 (November 4, 2020).

—. 2020b. "Taurat Dan Nubuat Palsu: Kajian Sudut Pandang Taurat Terhadap Nubuat Palsu." Jurnal Teologi Berita Hidup 2(2): 94-109. Http://E-

Journal.Sttberitahidup.Ac.Id/Index.Php/Jbh/Article/View/31.

Mawikere, Marde Christian Stenly. 2018. "Efektivitas, Efisiensi Dan Kesehatan Hubungan Organisasi Pelayanan Dalam Kepemimpinan Kristen.” Evangelikal: Jurnal Teologi Injili Dan Pembinaan Warga Jemaat 2(1): 50-67. Http://Sabda. (November 25, 2020).

Nainggolan, Bartolomeus Diaz. 2019. “Analisis Ajaran Kitab Daniel Pasal 4pengakuan Raja Nebukadnezar Tentang Kuasa Allah Daniel.” Jurnal Koinonia 11(2): 11-21. Https://Jurnal.Unai.Edu/Index.Php/Koinonia/Article/View/2350/1708.

Najla, Fathin Najla. 2018. "Potret Perjuangan Tokoh Utama Menghadapi Konflik

Kehidupan Dalam Novel Sirkus Pohon Karya Andrea Hirata.” Asas: Jurnal Sastra 7(2): 100-108.

Https://Jurnal.Unimed.Ac.Id/2012/Index.Php/Ajs/Article/View/10020 (November 23, 2020).

Nel, Marius. 2018. "Pentecostal Ecumenical Impulses: Past And Present Challenges." In Die Skriflig/In Luce Verbi 52(1): 8. Doi:

Https://Doi.Org/10.4102/Ids.V52i1.2330\%09 (June 16, 2020).

Novita, Bambang Swasto Sunuharjo, And Ika Ruhana. 2016. "Pengaruh Kepuasan Kerja Dan Komitmen Organisasional Terhadap Kinerja Karyawan (Studi Pada Pt.

Telekomunikasi Indonesia, Tbk Witel Jatim Selatan, Malang).” Jurnal 
Administrasi Bisnis (Jab) 34(1): 38-46.

Http://Administrasibisnis.Studentjournal.Ub.Ac.Id/Index.Php/Jab/Article/View/13

15.

Pranoto, Minggus Minarto. 2017. “Kesembuhan, Penebusan, Dan Kebaikan Allah

Dalam Teologi Pentakostal.” Jurnal Abdiel: Khazanah Pemikiran Teologi,

Pendidikan Agama Kristen, Dan Musik Gereja 1(01): 81-98. Doi:

Https://Doi.Org/10.37368/Ja.V1i01.88 (April 28, 2020).

Purba, Junita. 2018. "Peranan Orangtua Kristen Dalam Membina Kepribadian

Remaja/Pemuda Gereja Pentakosta Indonesia Lorong Tujuh.” Didache Jurnal

Pendidikan Dan Teologi Pentakosta 1(1): 35-48. Http://E-

Journal.Sttrenatus.Ac.Id/Index.Php/Didache/Article/View/11/0.

Purba, Wagelman. 2019. "Karya Penyelamatan Yesus Kristus Dilakukan Dalam Status

Kerendahan Matius 1:21 Dan Maknanya Bagi Gereja Masa Kini.” Jurnal

Pendidikan Religius 1(1): 22-26.

Https://Jurnal.Darmaagung.Ac.Id/Index.Php/Jurnalreligi/Article/View/169.

Remikatu, Jefri Hina. 2020. “Teologi Ekologi: Suatu Isu Etika Menuju Eskatologi

Kristen.” Caraka: Jurnal Teologi Biblika Dan Praktika 1(1): 65-85.

Https://Ojs.Sttibc.Ac.Id/Index.Php/Ibc/Article/View/12 (November 25, 2020).

Setiawan, David Eko, And Dwiati Yulianingsih. 2019. "Signifikansi Salib Bagi

Kehidupan Manusia Dalam Teologi Paulus.” Fidei: Jurnal Teologi Sistematika

Dan Praktika 2(2): 227-46. Http://Www.Stt-Tawangmangu.Ac.Id/E-

Journal/Index.Php/Fidei (November 25, 2020).

Setyowati, Dwi Atni. 2019. “Konflik Kepemimpinan Dalam Pekabaran Injil: Sebuah

Pemaknaan Terhadap Perselisihan Paulus Dan Barnabas Dalam Kisah Para Rasul

15:35-41.” Jurnal Abdiel: Khazanah Pemikiran Teologi, Pendidikan Agama

Kristen, Dan Musik Gereja 3(1): 33-47. Http://Journal.Stt-

Abdiel.Ac.Id/Ja/Article/View/49 (June 7, 2021).

Siahaan, Harls Evan R. 2017. "Karakteristik Pentakostalisme Menurut Kisah Para

Rasul." Dunamis: Jurnal Penelitian Teologi Dan Pendidikan Kristiani 2(1): 12.

Doi: Https://Doi.Org/10.30648/Dun.V2i1.132 (June 17, 2020).

Silalahi, Junior Natan. 2019. "Paulus Sang Entrepreneur: Pembuat Tenda Sebagai 
Jembatan Penginjilan.” Visio Dei: Jurnal Teologi Kristen 1(1): 1-18.

Http://Jurnal.Sttstarslub.Ac.Id/Index.Php/Js/Article/View/9 (November 25, 2020).

Simbolon, Elvri Teresia. 2018. "Pentingnya Keterampilan Sosial Dalam Pembelajaran.”

Jurnal Christian Humaniora 2(1): 40-52. Http://E-

Journal.Iakntarutung.Ac.Id/Index.Php/Humaniora/Article/View/22.

Sitopu, Elisamark. 2020. "Memahami Dan Memaknai Berbagai Peraturan, Ketetapan,

Dan Hukum Dalam Taurat." Jurnal Christian Humaniora 4(1): 33-44. Http://E-

Journal.Iakntarutung.Ac.Id/Index.Php/Humaniora (November 17, 2020).

Soesilo, Yushak. 2018. "Pentakostalisme Dan Aksi Sosial: Analisis Struktural Kisah

Para Rasul 2:41-47.” Dunamis: Jurnal Teologi Dan Pendidikan Kristiani 2(2):

136-51. Doi: Https://Doi.Org/10.30648/Dun.V2i2.172 (June 17, 2020).

Stansell, Gary. 2011. "David And His Friends: Social-Scientific Perspectives On The

David-Jonathan Friendship." Biblical Theology Bulletin: Journal Of Bible And Culture 41(3): 115-31.

Http://Journals.Sagepub.Com/Doi/10.1177/0146107911413209 (June 7, 2021).

Subekt, Hasan Et Al. 2017. "Mengembangkan Literasi Informasi Melalui Belajar

Berbasis Kehidupan Terintegrasi Stem Untuk Menyiapkan Calon Guru Sains

Dalam Menghadapi Era Revolusi Industri 4.0: Revieu Literatur." Education And

Human Development Journal 3(1): 81-90.

Https://Journal2.Unusa.Ac.Id/Index.Php/Ehdj/Article/View/90 (November 18, 2020).

Sunariyanti, Sapto. 2020. "Penerapan Etika Kristen Dalam Pendidikan Anti Korupsi Di

Keluarga." Sanctum Domine: Jurnal Teologi 7(1): 107-20.

Https://Journal.Sttni.Ac.Id/Index.Php/Sdjt/Article/View/46 (November 25, 2020).

Supatra, Hendarto. 2019. "Mengenal Pentakostalisme Di Indonesia.” Jurnal Abdiel:

Khazanah Pemikiran Teologi, Pendidikan Agama Kristen, Dan Musik Gereja 3(2):

11-24. Doi: Https://Doi.Org/10.37368/Ja.V3i2.97 (April 29, 2020).

Susanta, Yohanes Krismantyo. 2018. '“Menjadi Sesama Manusia 'Persahabatan Sebagai

Tema Teologis Dan Implikasinya Bagi Kehidupan Bergereja.” Dunamis: Jurnal

Teologi Dan Pendidikan Kristiani 2(2): 103.

Sutoyo, Daniel. 2018. "Analisis Historis Terhadap Teologi Gerakan Pentakostalisme.” 
Dunamis: Jurnal Teologi Dan Pendidikan Kristiani 2(2): 167. Doi:

Https://Doi.Org/10.30648/Dun.V2i2.171 (June 17, 2020).

Takaendengan, Agnes Megy. 2018. “Analisis Sosio-Historis Terhadap Narasi

Kebangsaan Tradisi Yahwisme Menurut Teori Nasionalisme Modern.” Jurnal

Hibualamo Seri Ilmu - Ilmu Sosial Dan Kependidikan 2(1): 45-57.

Http://Journal.Unhena.Ac.Id/Index.Php/Hibsos/Article/View/46.

Tambunan, Elia. 2019. "Pentakostalisme Dan Teori Sosial Kontemporer.” Jurnal

Teologi Amreta 2(1): 99-129.

Http://Jurnal.Sttsati.Org/Index.Php/Sati/Article/View/48.

Tua, Eko Mulya. 2017. “Respon Daud Dalam Menghadapi Pergumulan: Studi Terhadap

Kitab Mazmur 3:1-9.” Evangelikal: Jurnal Teologi Injili Dan Pembinaan Warga

Jemaat 1(1): 75. Http://Journal.Sttsimpson.Ac.Id/Index.Php/Ejtiissn:2548-7868

(November 24, 2020).

Xiao, Angeline. 2018. "Konsep Interaksi Sosial Dalam Komunikasi, Teknologi,

Masyarakat.” Jurnal Komunika : Jurnal Komunikasi, Media Dan Informatika 7(2):

94-99. Https://Jurnal.Kominfo.Go.Id/Index.Php/Komunika/Article/View/1486

(November 23, 2020).

Yonathan, Danny. 2019. "Memahami Konsep Menyangkal Diri, Memikul Salib Dan

Mengikut Yesus: Sebuah Analisis Biblikal Lukas 9:23-26.” Jurnal Teologi Berita

Hidup 1(2): 121-37. Https://E-

Journal.Sttberitahidup.Ac.Id/Index.Php/Jbh/Article/View/14 (November 25, 2020).

Zaluchu, Julianus. 2019. “Profil Rasul Paulus Dalam Surat 1 Korintus Dan

Relevansinya Bagi Hamba-Hamba Tuhan Di Gereja Pantekosta Di Indonesia

Rungkut Surabaya.” Journal Kerusso 4(2): 10-22. Http://Jurnal.Sttii-

Surabaya.Ac.Id/Index.Php/Kerusso/Article/View/109 (November 25, 2020).

Zaluchu, Sonny. 2017. "Penderitaan Kristus Sebagai Wujud Solidaritas Allah Kepada

Manusia.” Dunamis: Jurnal Penelitian Teologi Dan Pendidikan Kristiani 2(1): 61.

Http://Www.Sttintheos.Ac.Id/E-Journal/Index.Php/Dunamis (November 17, 2020).

Zaluchu, Sonny Eli. 2018. “Analisis Kisah Para Rasul 15 Tentang Konflik Paulus Dan

Barnabas Serta Kaitannya Dengan Perpecahan Gereja.” Kurios (Jurnal Teologi

Dan Pendidikan Agama Kristen) 4(2): 107-17. Https://Www.Sttpb.Ac.Id/E- 
Journal/Index.Php/Kurios/Article/View/83.

_. 2019. "Eksegesis Kisah Para Rasul 2:42-47 Untuk Merumuskan Ciri

Kehidupan Rohani Jemaat Mula-Mula Di Yerusalem.” Epigraphe: Jurnal Teologi

Dan Pelayanan Kristiani 2(2): 72.

Http://Www.Stttorsina.Ac.Id/Jurnal/Index.Php/Epigraphe/Article/View/37

(November 11, 2019)

—. 2019. "Komitmen Organisasi Dalam Perspektif Alkitabiah: Sebuah Studi

Kuantitatif Di Yayasan C Surabaya.” Kharismata: Jurnal Teologi Pantekosta 1(2):

75-88. Http://Amr.Aom.Org/Cgi/Doi/10.5465/Amr.1984.4277628. (November 23, 2020).

Agama." Evangelikal: Jurnal Teologi Injili Dan Pembinaan Warga Jemaat 4(1):

28. Https://Journal.Sttsimpson.Ac.Id/Index.Php/Ejti/Article/View/167 (November $23,2020)$. 